\title{
PIK3CB wt Allele
}

National Cancer Institute

\section{Source}

National Cancer Institute. PIK3CB wt Allele. NCI Thesaurus. Code C51161.

Human PIK3CB wild-type allele is located in the vicinity of $3 q 22.3$ and is approximately $105 \mathrm{~kb}$ in length. This allele, which encodes phosphatidylinositol-4,5-bisphosphate 3kinase catalytic subunit beta isoform protein, plays a role in signaling pathways underlying the regulation of apoptosis, cell growth, and angiogenesis. 